\title{
Re-branding Landscapes of Forgotten Resorts. Case of the Healing Resort Kemeri in Latvia
}

\author{
Natalija N,itavska, Daiga Skujāne, Latvia University of Life Sciences and Technologies, Latvia
}

\begin{abstract}
Health resorts have been important landscape identity elements and economy drivers in European cities since the beginning of their development. The sea coastal area in Latvia is rich in sulphur springs that have been used for health procedures since 19th century. Kemeri resort in Jurmala City is known as a unique place that got its name from the forester house Kemeres where the first health procedures were performed by using sulphur spring mud. In 1836 Kemeri was declared as a resort and became known in the whole Russian Empire and later also in the Soviet Union. Significant landscape changes occurred after Latvia regained its independence in 1990, when the ownership of the land changed from the state to the private. Affected by disagreements between the new owners, lack of private and state investments, decrease of visitors from former Soviet Republics, insufficient capacity for competing with European resorts, the resorts in Latvia often became abandoned and forgotten. Historically valuable buildings and parks of the resorts were degraded, the number of inhabitants and visitors decreased. Today the regional government has found opportunities for re-development of Kemeri resort by searching for a new identity and re-branding the place. Re-branding has been used to enhance attractiveness of the place and increase economic benefits. Therefore, the aim of the study is to identify historic heritage values suitable for re-branding of the place and to analyse a potential development of the resort Kemeri. Assessment part of the article is based on historic heritage study by comparing historic and modern photography, field surveys to identify historic heritage values of the place and their influence on possible development scenarios. Historic heritage values were identified according to the Historicity and authenticity; Aesthetic quality and integrity; Social meaning. The other parts of the article are addressed to re-branding of the place that includes involvement of identified historic heritage values into the new identity to enhance functionality, recognisability and attractiveness of the resort Kemeri.
\end{abstract}

Keywords: forgotten places, health resorts, landscape revitalization

\section{Introduction}

Due to the impact of political and natural processes, cities can become abandoned. As a result, population is decreasing, places are becoming forgotten and degraded. In most cases, it is caused by different political events - change of political power and regime, land reforms, wars; or natural factors - natural disasters, forest fires, flooding etc. Revitalization of forgotten and degraded places is a great challenge for local governments $[1 ; 9 ; 7]$. The article reflects revitalization project of the former health resort Kemeri in Jurmala City, Latvia by using re-branding principles.

\section{Re-branding places}

A common definition found in different resources states that a brand is something that distinguishes one product from another in the eyes of the customer. This could be name, style, symbol, quality of product, process etc. and involves some degree of expectations and imaginations. Place, city or town branding is a complex of activities planning, production, governing and promoting specific and unique objects, products, activities in order to compete with other places in tourist attraction, investments, new residents, national and global events etc. $[1 ; 11 ; 4]$.
Re-branding is more related to the territories that have lost their identity and attractiveness due to some specific reasons. Therefore the main aim of place / city / town re-branding is to shape a new identity and to promote economic potential of the area. There are different types of re-branding according to the scale of the place (national, city, town, village, and place) or some specific values of the area (agriculture, nature, healing potential etc.) $[3 ; 4]$.

Forgotten health resorts in Latvia and the need for re-branding

Mud and hydrotherapeutic resorts in Latvia have more than a hundred-year history. Till the 90ies of the 20th century most of them were oriented to the tourists from the Soviet Union. There operated 9 resorts, more than 30 sanatoriums and spa institutions in the coastal city Jurmala. After Latvia regained its independence in 1990 the business of health resorts decreased. Today we can find only 4 actively functioning specialized sanatoriums in Jurmala. Reasons of the decline are mostly connected with political factors. Those are changes of ownership from state in Soviet period to private, political decisions about non-investment of EU 

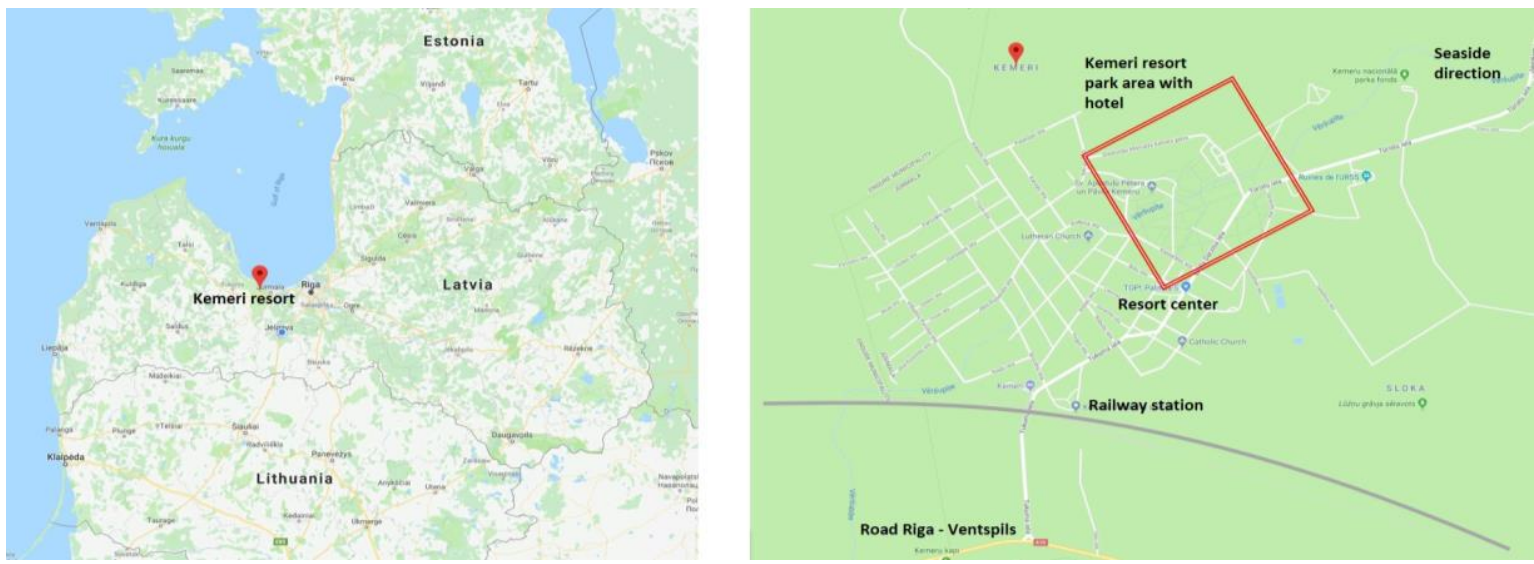

Fig. 1. Location of Kemeri resort in Latvia and Jurmala City on google maps

funds into re-branding and redevelopment of Latvia heath resorts, low competiveness with European resorts due to a poor comfort level that required major repairs of buildings and infrastructure $[9 ; 12]$.

The aim of the particular study is to identify nature, culture and social values suitable for the place re-branding and to analyse potential development of the resort Kemeri in correlation with the main principles of re-branding.

\section{Material and Methods}

\section{Research area}

The study observes former health resort Kemeri in Latvia. Kemeri resort is a part of Jurmala city located in the sea coastal area of the Gulf of Riga (Fig. 1). The total area is $13,8 \mathrm{~km}^{2}$, number of inhabitants -1962 . Kemeri resort has important mineral water and therapeutic mud resources that were economic drivers for the resort since the end of the 19th century [12]. Since 1836, Kemeri was well known as the healing resort in the whole Russian Empire and later in the Soviet Union. The number of visitors reached 21000 in 1965 , when there were 8 sanatoriums and 29 operating sulphur springs. After Latvia left USSR in 1990, Kemeri resort met the same problems as all the resorts in Latvia, and soon it became forgotten and started to get degraded [9]. Today Kemeri resort is facing new challenges to become one of Latvia brands again.

Kemeri resort has several statuses. It is a monument of the state importance of city building. The park of Kemeri resort and several historic buildings (architect E.Laube) and elements located in the park are monuments of the state importance of architecture.

\section{Methodology}

The re-branding of Kemeri resort is based on enhancement of economic potential of the place by promoting its visibility in local and national markets, attracting tourists, investors and potential inhabitants. The methodology of Kemeri resort re- branding included two steps - identification of nature, culture and social values and the use of identified nature, culture and social values in addition to new functions.

Identification of nature, culture and social values of the place existed in the past and today by comparison of historic photography and maps of today`s situation in Kemeri resort $[1 ; 2 ; 9]$. The aim of this activity is to evaluate a potential impact of detected values on the development of the place and the possibility to use them into re-branding of Kemeri resort. Values were evaluated according to the attributes $[13 ; 7]$ :

- Historicity / authenticity represents connections between the past and today. Those are all elements that represent important nature processes (for example, still existing oak forest, swamp, sulphur springs) or human activities (buildings, network of streets, artificial water elements, terrain, greenery etc.) and still can be found in the area.

- Integrity and aesthetic quality represents harmony of historic elements especially from different historic periods. The activity includes evaluation of composition, scale, proportions etc. of materials, greenery system / design, architectural elements, landscape spatial structure remained from different periods. The activity helps to find best solutions for the development of the place and to detect which elements should be highlighted and used for rebranding of the place.

- Social importance shows to what extent the place symbolizes events, elements, activities and traditions which are important for local / national community. The social importance is evaluated in context of similar places of a local, regional or national importance. What was more different and unique in the development of a particular place and how to make it more visible? The most difficult part of this activity is to choose which of the historic periods 


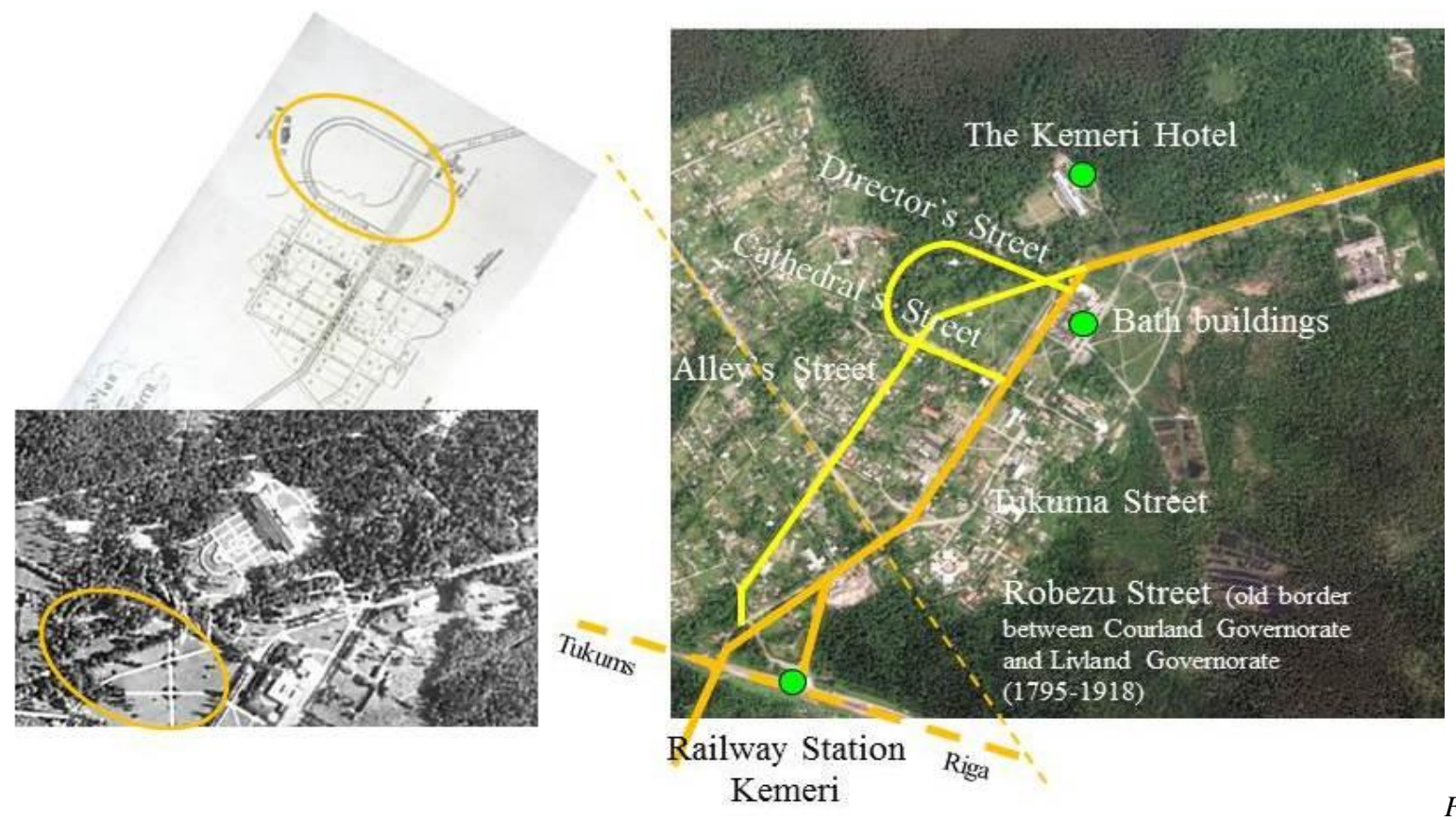

ig 2. Identified old streets and main directions as connecting element with historical events

will be the base for a new face of the place. Will those be elements most remained for one of historic periods or some specific and unique separate elements?.

Use of identified nature, culture and social values in addition to new functions for the development of a new image, identity of the place, re-branding of Kemeri resort.

Each of identified values are evaluated according to the main principles of re-branding - to promote place as a tourist destination, an attractive place for investors and potential inhabitants. How are detected values important in re-branding process? And how could they be used to make the re-branding more effective $[1 ; 2 ; 3 ; 4]$ ?

\section{Results and Discussions}

\section{Key elements for re-branding Kemeri resort}

Key elements for re-branding Kemeri resort are grounded in the origin of the resort. The research on historic information showed that the key elements of the origin and development of the resort were unique sulphur springs in Latvia, as well as natural environment and elements - forests with oak-trees (Quercusrobur), linden (Tiliacordata), elm trees (Ulmusglabra; Ulmuslaevis), and ash trees (Fraxinus excelsior), small rivers, lakes and swamps. First healing activities with the use of mud and mineral water from sulphur springs dated to the beginning of the 19th century. At that time patients also used local forests for walks and other activities. Based on the long history of nature resource use in Kemeri area, identity and brand elements of the place were also highlighted in the revitalization and re-branding project of Kemeri resort.
Old streets and directions - the base of the main axes of the resort landscape

Till the end of the 20th century Kemeri resort has grown from a few buildings into a town with good infrastructure and connectivity with the largest cities of Latvia. Old streets became important landscape elements as they represented the history of Kemeri development, marked the main directions and determined the compositional structure of the landscape $[9 ; 2]$. It is also possible to find the remains of the town structure nowadays (Fig. 2). One of the most important axis in the past and also today is Tukuma Street. It was the main link to the railway that connected Kemeri with Riga (the capital of Latvia) and even Russia. Also today Tukuma Street is one of the central compositional axes in Kemeri resort complex. Robezu (in English Border) Street represents old border area between Courland Governorate and Livland Governorate (1795-1918). We can find Director's Street in Kemeri park area. In the 19th century it directed visitors of the resort to the main building and divided the central park of the resort into wild and "cultivated" parts. Alley Street reflects a long history of planting alleys in Kemeri resort.

The main old axes and directions are kept as linkages with the history and roots of the place also in the revitalization project of Kemeri resort.

\section{Historic buildings with new functions}

Kemeri town got its status as a resort in 1836, but its development peak was the beginning of 20 th century. At that time there were different type and size bath buildings, post office, Catholic, Lutheran and Orthodox churches for visitors of 


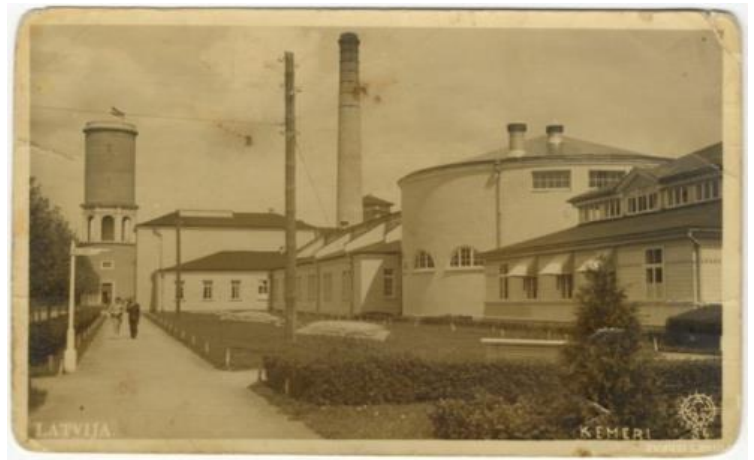

Fig. 3. Bath buildings and water tower on Tukuma Street, $1936[6 ; 5]$

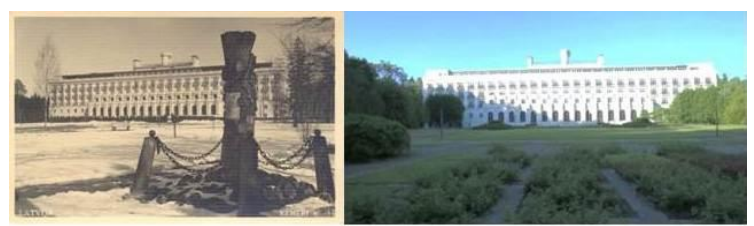

Fig. 4. White building of the Kemeri hotel, 1936 [6; 5] and 2017

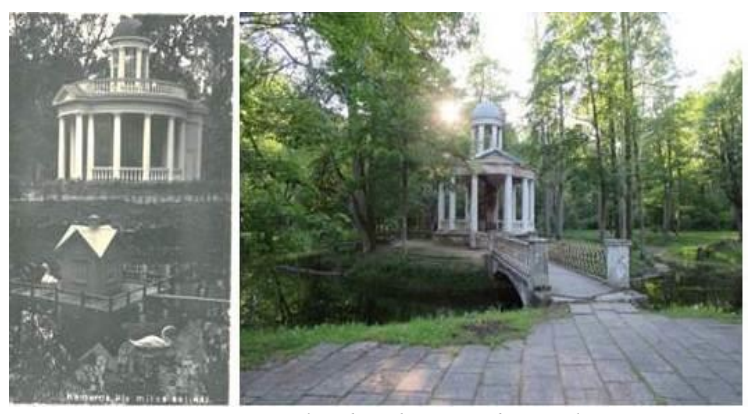

Fig. 5. Love Island with rotunda pavilion, 193-.[5; 6] and 2017
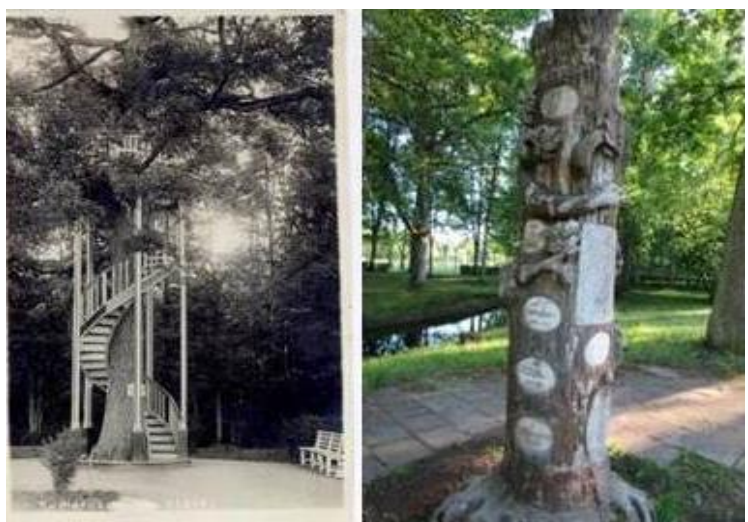

Fig. 6. Love oak tree (not exists) [5] and the monument for the first developers and directors of Kemeri resort, 2017

different confessions, more than 200 summer cottages, 12 pensions and hotels.

After World War I most of the buildings and the park were destroyed, but very soon the resort was one of the most demanded in Latvia again. At that time Kemeri had its own power and water supply, sewerage system. Today, one of the landmarks of the resort is 45 meter high water tower. In the past, it had two reservoirs for drinking and sulphur water, and sightseeing platform on the top1 (Fig. 3.).

The other landmark of Kemeri resort is Kemeri hotel white building that was built in 1936 and provided different activities throughout the year (Fig. 4.). When the number of visitors from the former Soviet Republics decreased, most of buildings for sulphur spring mud therapies were not used anymore and became degraded.

There are several architectural elements that promote attractiveness of Kemeri resort. Those are pavilions, small bridges, benches, sculptures etc. (Fig. 5.)

One of the most famous architectural elements of Kemeri park is the monument (1896) in the shape of the tree dedicated to the first directors and developers of Kemeri resort (Fig. 6.).

In the revitalization project of Kemeri resort, the main important buildings are planned to be used as visual landmarks of the place. The functions of the building will be supplemented or change to new according to the arrival of new technologies and needs of visitors.

In the revitalization project, the water tower will not be used as water reservoirs anymore, but will provide place for tourists information centre, exhibition and a view platform. Kemeri hotel besides hotel functions will serve new ones - place for conferences and seminars, spa and sports area etc.

\section{Green spaces with high biodiversity symbolizing environmental quality for good health}

Positive effects on patients from forests of Kemeri resort are described by several authors. Forests of Kemeri resort were formed as landscape parks by supplementing them with a large number of introduced species of trees, shrubs and perennial plants. The diversity of plant material was initiated and provided by the first gardener of Kemeri resort, owner of Riga nursery K.H. Vagners (1785.-1846.). The diversity of plant species is also kept in the revitalization project of Kemeri resort for better connection with existing nature of this place.

Other important elements are alleys and hedgerows. In the analyses of historic literature and photos, it was found that almost all streets and pedestrian trails are enclosed with alleys and hedgerows of different species of trees, shrubs and perennial plants (Fig. 7.).

Today old alleys and hedgerows are in low quality because of poor maintenance during the last 25 years.

Historic materials show that since the beginning of 20th century there were two types of green spaces 


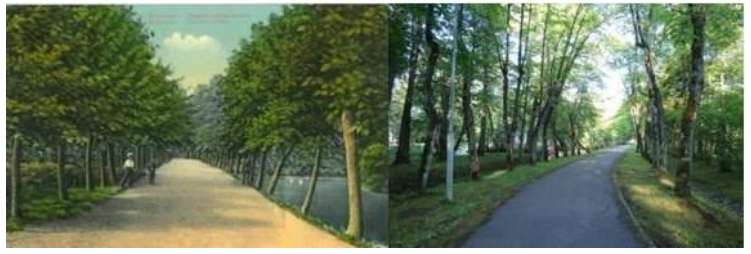

Fig. 7. Alleys of the Kemeri park in historic pictures [5; 6] and today (Director's Street)
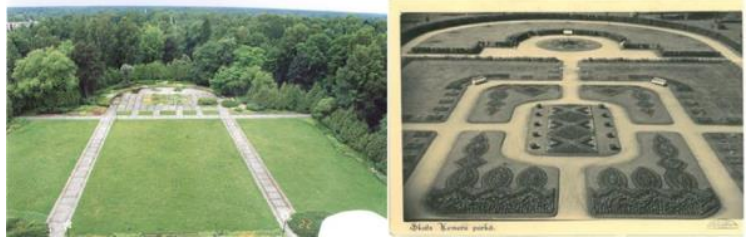

Fig. 8. Design and plantings of the ornamental parterre part, 1936 [5] and 1960 [6]

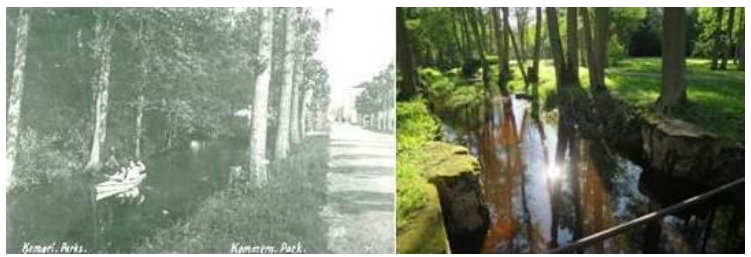

Fig. 9. Channels of the Versupite River. Boating (193-.) [5]. Former water sluice gate, 2017 year

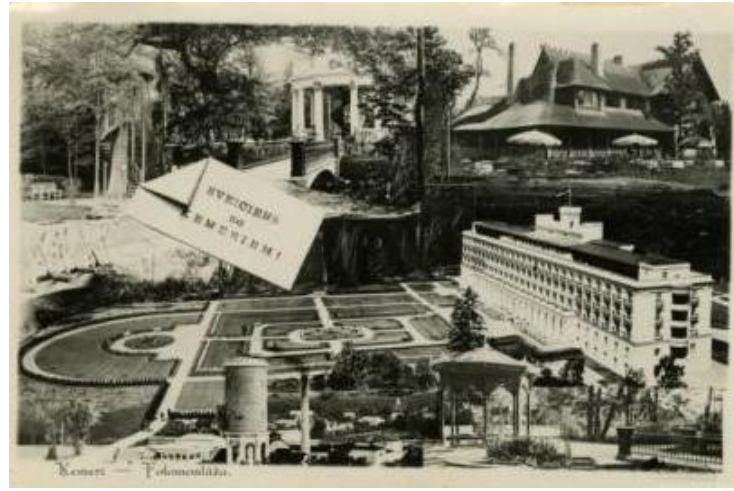

Fig. 10. Set of photographs representing activities of Kemeri resort, 193-. [5; 6]

in Kemeri resort - urban forest with pedestrian trails and wild vegetation; and "cultivated park" with a large number of introduced plants. Trends of that period were thuja trees (Thuja) and white robinia trees (Robiniapseudoacacia) that can still be found in the park areas of Kemeri resort. The diversity and colourfulness of the Kemeri park greenery as positive and unforgettable elements are highlighted in many evidences of that time.

New tendencies in the design and composition of Kemeri park arrived together with Kemeri hotel built in 1936. According to the architectural style of the building the composition of the plantings is developed in the style of classicism with symmetrical design of ornamental parterre in front of the hotel and bath buildings. Plantings of the style of classicism could be read only from historic photography. Today, in the park and near buildings, we can find plantings designed in 1960
They have typical of that time attributes - large and irregular areas with perennials, ground covered by concreate plates, decorative retaining walls from stone (Fig. 8.).

Last 25 years, Kemeri resort has been left without any significant interruption to its development. It is affected the green spaces of Kemeri resort both ways. It is positive, that we can find old, beautiful trees and great biodiversity, but there are also many problematic places - broken and unsafe infrastructure elements, overgrown plantings, tree seedlings have grown as big trees and overshadow park area.

The revitalization project of the park of Kemeri resort is based on compromise between the design of the classicism that is more appropriate for the architectural style of Kemeri hotel, and the existing diversity of plants that can be found in the park area nowadays.

\section{Landscape for active participation}

Since its foundation, Kemeri resort has had not only healing function, but also provided different activities for patients after their therapies. First of all, those were activities in the nature - walks in the forests, sunbathing, sport activities etc. Since the end of the 19th century, indoor and outdoor spaces were also developed for entertainment activities, music, dancing, reading, gaming, restaurant and library.

After World War I, the café was located on the Love Island with the access to the water channels. At that time, channels of small river Versupite were suitable for boating. The set of water sluice gates was built for this purpose. Today this system does not work anymore (Fig. 9.).

In 30 ies of the 19 th century, international chess competitions were organized to promote Kemeri resort. In historic materials we can find that social activities were important elements of the identity and recognisability of Kemeri resort (Fig. 10.).

Revitalization and re-branding project of Kemeri resort and its park

Due to specific conditions of Kemeri resort that are connected with different historic landscape layers found in the area, the re-branding and revitalization project of Kemeri resort divides the area into four parts - ornamental parterre part in front of Kemeri hotel building, active part, forest park part and forest wild part (Fig. 11.). Each of the parts has its own specific attributes, as well as requirements for planning, protection and management.

The Ornamental parterre is developed as one unit with Kemeri hotel and is planned as one of the landmarks of the resort. The design of the green space is based on the symmetry and includes plantings with formed hedgerows and flowering plants, as well as architectural elements - benches, 


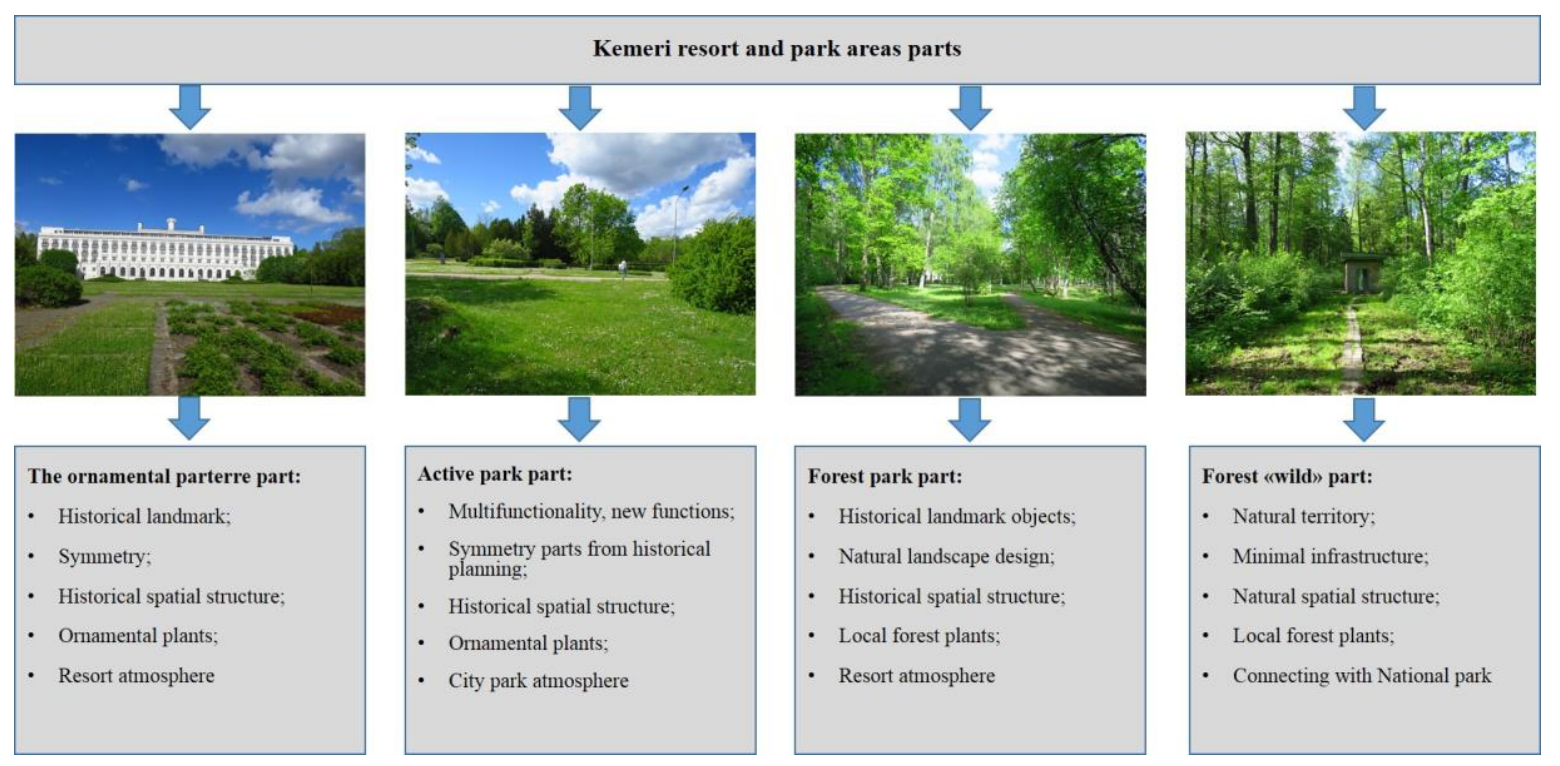

Fig. 11. Kemeri resort and park areas, with [10]. - ornamental parterre, 2. - Active area, 3. - Forest park, - Forest "wild" area, 2017

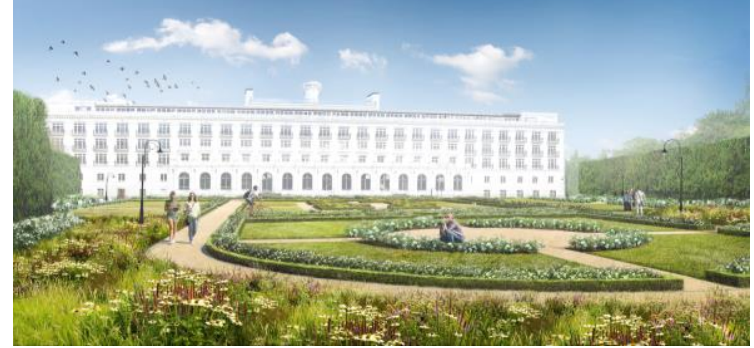

Fig. 12. Ornamental parterre with the symmetrical structure and a large number of perennial plants [project authors visualization, technical 3D drawing A.Mengots]

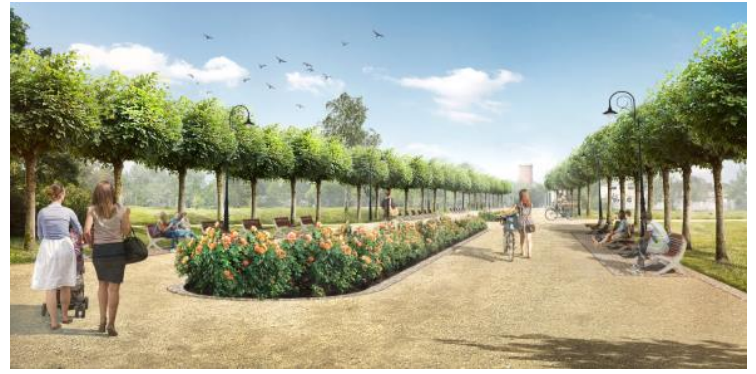

Fig. 13. Active part with central composition axis with water tower and alleys [project authors visualization, technical 3D drawing A.Mengots]

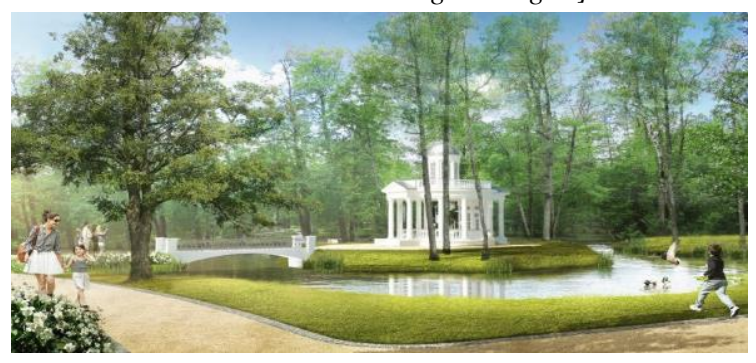

Fig. 14. New design of Love Island with rotunda [project authors visualization, technical 3D drawing A.Mengots] sculptures etc. Flowering plants reflect white colour of the building of Kemeri hotel. As a compromise, there are existing old trees left that were not in the original plan (1936), but now can be found in the area and influence new design of the ornamental parterre [10] (Fig. 12.).

The Active part of Kemeri resort park is more open visually and functionally, but still has a clear composition and the spatial structure that corresponds to the historic period of its development. Alleys, hedgerows, flowering and colourful plantings are used to establish connection with the historic values of the place (Fig. 13.). There are new functions added to this place - exhibition and entertainment squares, recreation places, children playground [10].

The Forest park is a "cultivated" part of forest with open spaces, groups of trees, cultural heritage objects and elements - Love Island with rotunda pavilion, Orthodox church, bridges, monument for the first directors and developers of the resort. The main function of the Forest park part is to connect the Active part and Forest "wild" part of the park. The Forest park keeps the historic structure of the landscape and nature values - diversity of local plant species, river Versupite with natural banks, old trees and groups of trees, specific habitats for bats and insects [10] (Fig. 14.).

The Forest "wild" part is spatially closed forest area with separate open spaces, pedestrian trails and architectural elements. This part will be kept as natural biotope for highlighting nature values of Kemeri resort. 


\section{Conclusions}

The landscape of Kemeri resort has been changed several times and influenced by political processes, ideology and trends of the historic periods. However, the mental image of the place was always determined by presence of sulphur springs and their use for medical therapies, but the visual and spatial image of Kemeri resort - by nature values (a large number and diversity of plant species, where next to the native species new ones were introduced, a large number of perennial plants, alleys and formed hedgerows were used) and cultural heritage of the place. Therefore, nature and heritage values are defined as one of the key and brand elements for the new identity of the place.

Other key elements for the branding of Kemeri resort are: old streets and historic directions that can be used as a connection between the past and today, and the base for composition and spatial structure of Kemeri resort landscape.
The most problematic issue was how to make the unity between the landscape elements of different historic periods and styles. Each of time periods has left its mental message. Therefore, the new image of the place is developed as a compromise between the elements of different historic periods. The composition and landscape structure is developed in the style of classicism taken from the development time of Kemeri hotel, but the principles of plantings are used from the Soviet era where a large number and diversity of plant species was used.

The social activities also are key elements for the re-branding of the place. We can find them already in the origins of Kemeri resort. Social activities will provide extra interest from possible visitors to experience the place not only for medical therapies, but also for living and working.

\section{References}

1. Benett R., Savani S. The Rebranding of City Places: An International Comparative Investigation. In: International Public Management Review, Vol. 4, No. 2, 2003, p.70-87

2. Bradley A., Hall T., Harrison M.Selling Cities. Promoting New Images for Meetings Tourism. In: Cities, Vol. 19, No. 1., 2002, p. 61-70

3. Hanna S., Rowley J. An Analysis of Terminology Use in Place Branding. In: Place Branding and Public Diplomacy, Vol. 4, No. 1, 2008, p. 61-75

4. Herstein R. Thin Line between Country, City, and Region Branding. In: Journal of Vacation Marketing, Vol.18, No. 2, 2011, p.147-155

5. Historic photography of Kemeri resort. [online 25.08.2010.]. www.zudusilatvija.lv

6. Inventory of architectural and cultural heritage of Kemeri resort park, 2010

7. Jokilehto J. Considerations on authenticity and integrity in world heritage context. In: City \& Time 2 (1): 1, 2006

8. Maps and aero photography of Kemeri resort. [online 20.08.2010.]. https://kartes.lgia.gov.lv

9. Pavuk O., Salajeva M.Overcoming the Depressiveness of the Resort City Jurmala by Creational Zone in the Region. In:Macroeconomics: Development of Productive Forces and Regional Economy, Vol. 6, No. 5, 2017, p.15-19

10. Project description on municipality home page.

https://www.jurmala.lv/lv/sabiedriba/jaunumi_aktuali/pasvaldiba/59028-pieteiks-projektu-kemeru-parka-atjaunosanai

11. Sevin H.E. Understanding Cities through City Brands: City Branding as a Social and Semantic Network. In:Cities, Vol. 38, 20014, p. 47-56

12. Skapare I., Kreslins A. Research of Available Mineral Geothermal Water resources for Utilization in Latvian Sanatoriums. In: Proceedingd of World Geothermal Congress, 25 - 29 April, 2010, Bali, Indonesia, p. 1-5.

13. Stovel H. Effective use of authenticity and integrity as world heritage qualiifying conditions. In: City \& Time 2 (3): 3, 2007

\section{AUTHORS:}

Daiga Skujāne, Dr. arch., Professor, leading researcher, landscape architect. Academic and research experience is more than ten years, currently is working as a professor and a leading researcher at the Department of Landscape Architecture and Planning and the Dean of the Faculty of Environment and Civil Engineering, Latvia University of Life Sciences and Technologies (LLU). The main academic and scientific topics - ecology and aesthetics of landscape, ecological design and landscape planning in climate change conditions. Has teaching experience as a lecturer in bachelor, master and doctoral study programmes in landscape architecture and planning (LLU), in BOVA university (network of Baltic agricultural universities), in annual international summer schools, in LLU Lifelong education centre programmes, as well as the lecturer for incoming foreign students in ERASMUS+ programme. Has experience in academic and research projects. The author of more than twenty five articles in international journals and conference proceedings.

Natalija N,itavska, Dr. arch., Professor, a leading researcher, a landscape architect. The Head of the Department of Landscape Architecture and Planning, the director of the bachelor and master study programmes in landscape architecture and planning at University of Life Sciences and Technologies (LLU). Academic and research experience is more than ten years, is currently working as an associated professor and a leading researcher at the Department of Landscape Architecture and Planning, LLU. The main academic 
and scientific topics are addressed to sea coastal landscapes, cultural and natural values of landscapes, landscape architecture. Has teaching and organizing experience in different level courses in landscape architecture and planning bachelor, master and doctoral study programmes (LLU), in BOVA university (network of Baltic agricultural universities), in annual international summer schools, in LLU Lifelong education centre programmes, as well as the lecturer for incoming foreign students in ERASMUS+ programme. Has experience in academic and research projects. The author of more than twenty five articles in international journals and conference proceedings.

Kopsavikums. Aizmirstu un izpostītu vietu atdzīvināšana ir liels izaicinājums pašvaldībām. Rakstā atspoguḷots bijušā kūrorta Ķemeri (Jūrmalā) ainavas atjaunošanas projekts, balstoties uz vietas identitātes izmantošanu, ka jaunu zīmolu, atjaunojot teritorijas funkcijas. Dūṇu un hidroterapeitiskajiem kūrortiem Latvijā ir vairāk nekā simts gadu vēsture. Līdz 20. gadsimta 90. gadiem vairums no viņiem bija orientēti uz tūristiem no Padomju Savienības. Piekrastes pilsētā Jūrmalā darbojās 9 kūrorti, vairāk nekā 30 sanatorijas un SPA iestādes. Pēc Latvijas neatkarības atgūšanas 1990. gadā samazinās kūrortu bizness. Mūsdienās Jūrmalā var atrast tikai četras aktīvi funkcionējošas specializētās sanatorijas. Lejupslīdes iemesli galvenokārt saistīti ar politiskiem faktoriem. Tās ir îpašumtiesību maiņa no valsts padomju laikā uz privātiem, politiski lēmumi par neieguldījumiem no ES fondiem Latvijas veselības kūrortu pārzīmēšanai un atjaunošanai, zema konkurētspēja ar Eiropas kūrortiem sliktā komforta līmeņa dēl, kas prasīja kapitālo remontu, kopēja pilsētvides infrastruktūra. Konkrētā pētījuma mērḳis ir identificēt dabas, kultūras un sociālas vērtības, kas piemērotas vietas identitātes atjaunošanai, un analizēt Ķemeru kūrorta potenciālo attīstību saistībā ar galvenajiem identitātes saglabāšanas principiem. Visproblemātiskākais jautājums bija par to, kā panākt vienotību starp dažādu vēsturisko periodu un stilu ainavas elementiem. Katrs no laika periodiem ir atstājis savu garīgo vēstījumu. Tāpēc jauns vietas tēls tiek veidots kā kompromiss starp dažādu vēsturisko periodu elementiem. Kompozīcija un ainavas struktūra ir veidota klasicisma stilā, kas ņemts no Ķemeru viesnīcas sākotnējas attīstības laikiem, bet stādīšanas principi tiek izmantoti no padomju laikiem, kur tika izmantots liels augu sugu skaits un daudzveidība, kas arī mūsdienās ir svarīgs ekologiskās daudzveidības pamats. Ne mazāk svarīga loma ir arī sociālām aktivitātēm, tāpēc jauns plānojums balstās uz daudzveidīgo funkciju nodrošināšanu parka teritorijā. 